EDUTECH : Jurnal Inovasi Pendidikan Berbantuan Teknologi

Vol. 2 No. 1 Februari 2022, e-ISSN : 2797-0140 | p-ISSN : 2797-0590

\title{
MENINGKATKAN KEMAMPUAN KOMUNIKASI (COMMUNICATION SKILL) DAN HASIL BELAJAR SISWA MELALUI PEMBELAJARAN SAINTIFIK DENGAN MEMANFAATKAN MEDIA INFOGRAFIS
}

\author{
RIZAWATI \\ SMAN 1 Bengkulu Utara \\ e-mail: watiriza5@gmail.com
}

\begin{abstract}
ABSTRAK
Penelitian ini dilatarbelakangi oleh rendahnya kemampuan komunikasi dan hasil belajar siswa di kelas XI MIPA 1 SMAN 1 Bengkulu Utara. Kemampuan komunikasi menjadi salah satu kompetensi abad 21 yang harus dikuasai oleh siswa. Hal ini perlu menjadi perhatian dan dicarikan solusi dan strategi dalam pembelajarannya. Salah satu strategi yang dapat dilakukan oleh seorang guru adalah melalui pembelajaran saintifik dengan memanfaatkan media infografis. Penelitian ini bertujuan untuk mendeskripsikan proses pembelajaran melalui penerapan pendekatan saintifik dengan memanfaatkan media infografis, mendeskripsikan proses peningkatan kemampuan komunikasi ( communication skill) dan hasil belajar siswa pada mata pelajaran Biologi di kelas XI MIPA 1 SMAN 1 Bengkulu Utara Tahun Pelajaran 2021/2022. Jenis penelitian ini adalah penelitian tindakan kelas. Penelitian ini memiliki prosedur tindakan yang diawali dengan merencanakan, tindakan, observasi, dan refleksi. Penelitian ini berlangsung selama tiga siklus dengan sabjek 31 siswa kelas XI MIPA 1 pada semester ganjil Tahun Pelajaran 2021/2022. Hasil penelitian menunjukkan terjadi peningkatan kemampuan komunikasi dan hasil belajar siswa melalui pembelajaran saintifik dengan memanfaatkan media infografis. Hal ini ditunjukkan dengan hasil penelitian bahwa proses pembelajaran saintifik berjalan sesuai dengan urutan langkah-langkah saintifik di siklus I terlaksana $78 \%$, pada siklus II meningkat menjadi $88 \%$ dan pada siklus III meningkat menjadi 95\%. Seiring peningkatan proses pembelajaran saintifik dengan memanfaatkan media infografis terjadi peningkatan pada kemampuan komunikasi siswa dari siklus I sebanyak 5 orang siswa, siklus II menjadi 8 orang siswa dan disiklus III menjadi 14 orang siswa sudah melebihi dari indikator keberhasilan yakni 10 orang siswa. Hasil belajar siswa mengalami peningkatan yang bermula di siklus I yakni 9,68\% siswa yang mencapai KKM, pada siklus II menjadi $45,16 \%$ dan pada siklus III meningkat menjadi 77,42\%. Dengan demikian dapat disimpulkan bahwa pembelajaran saintifik dengan memanfaatkan media infografis dapat meningkatkan kemampuan komunikasi dan hasil belajar siswa kelas XI MIPA 1 SMAN 1 Bengkulu Utara Semester Ganjil Tahun Pelajaran 2021/2022.
\end{abstract}

Kata Kunci: pembelajaran saintifik, media infografis, kemampuan komunikasi.

\begin{abstract}
This research is motivated by the low communication skills and student learning outcomes in class XI MIPA 1 SMAN 1 Bengkulu Utara. Communication skills are one of the 21st century competencies that must be mastered by students. This needs to be a concern and find solutions and strategies in learning. One strategy that can be done by a teacher is through scientific learning by utilizing infographic media. This study aims to describe the learning process through the application of a scientific approach by utilizing infographic media, to describe the process of improving communication skills and student learning outcomes in Biology subjects in class XI MIPA 1 SMAN 1 Bengkulu Utara in the 2021/2022 academic year. This type of research is classroom action research. This research has an action procedure that begins with planning, action, observation, and reflection. This research took place in three cycles with the subjects of 31 students of class XI MIPA 1 in the odd semester of the 2021/2022 academic year. The results showed that there was an increase in communication skills and student learning outcomes through scientific learning by utilizing infographic media. This is indicated by the results of the study that the scientific learning process runs according to the sequence of
\end{abstract}


scientific steps in the first cycle carried out $78 \%$, in the second cycle increased to $88 \%$ and in the third cycle increased to $95 \%$. Along with the improvement of the scientific learning process by utilizing infographic media, there was an increase in students' communication skills from cycle I as many as 5 students, cycle II to 8 students and cycle III to 14 students already exceeding the success indicator, namely 10 students. Along with the improvement of the scientific learning process by utilizing infographic media, there was an increase in students' communication skills from cycle I there were 5 students, cycle II became 8 students and cycle III became 14 students, exceeding the success indicator, namely 10 students. Student learning outcomes have increased starting in the first cycle, namely $9.68 \%$ of students who achieved the $\mathrm{KKM}$, in the second cycle it became $45.16 \%$ and in the third cycle it increased to $77.42 \%$ Thus, it can be concluded that scientific learning by utilizing infographic media can improve communication skills and student learning outcomes of class XI MIPA 1 SMAN 1 Bengkulu Utara Odd Semester for the 2021/2022 Academic Year.

Keywords: scientific learning, infographic media, communication skills.

\section{PENDAHULUAN}

Sejalan dengan kecakapan abad 21 di mana kecakapan berkomunikasi atau communication skill merupakan salah satu dari empat kecakapan yang harus dimiliki siswa. Kemampuan ini sangat penting untuk dimiliki siswa, mengingat kehidupan di era global yang semakin kompetitif. Kecakapan berkomunikasi tidak datang dengan sendirinya, kecakapan ini perlu dibiasakan dan dilatih dalam proses belajar sehingga tercetak generasi yang siap menjawab tantangan zaman.

Kenyataannya kemampuan komunikasi dalam pembelajaran oleh siswa di SMAN 1 Bengkulu Utara masih kurang. Hal ini dapat dilihat dari dalam berkomunikasi di kelas, siswa sangat susah sekali untuk memberikan pendapat, ataupun bertanya. Mempresentasikan laporan diskusi di depan kelas, masih terlihat siswa membaca laporan tanpa melihat temannya, dan menyusun kalimat dalam berkomunikasi masih menggunakan Bahasa daerah.

Berdasarkan wawancara dengan siswa, hal yang menyebabkan siswa demikian adalah kurangnya pemahaman terhadap materi karena kurangnya minat membaca. Alasanya karena sajian materi pada buku membosankan, full teks, tidak interaktif. Kecendrungan siswa sekarang ini lebih senang memegang gadget yang memuat gambar, warna, gambar bergerak. Kurangnya minat membaca tentu membuat siswa kurang wawasan tentang materi pelajaran, sehingga mereka tidak memahami materi dan akhirnya tidak punya keberanian untuk mengkomunikasikannnya. Penulis juga melakukan pengamatan kepada kebiasaan teman sejawat mengajar. Berdasarkan pengamatan penulis, guru-guru di SMAN 1 Bengkulu Utara kecendrungan mengajar secara konvensional. Guru lebih banyak menjelaskan materi sehingga siswa tidak ada kesempatan untuk berkomunikasi secara lisan.

Kurangnya minat membaca siswa, sehingga kurang memahami materi mengakibatkan hasil belajar juga rendah. Usaha yang pernah penulis sendiri lakukan dalam mengajar selama ini menggunakan power point (PPT). Namun karena mempelajari beberapa slide dalam power point (PPT) belum dapat meningkatkan kecakapan komunikasi dan hasil belajar siswa. Untuk itu penulis mencoba menganti media pembelajaran dengan media infografis.

Media infografis merupakan media pembelajaran berbasis digital. Secara fisik media infografis berisi informasi materi yang didesain semenarik mungkin dengan visualisasi gambar, warna yang menarik. Media infogarfis juga bisa disisipi video atau animasi sehingga pembelajaran menjadi interaktif. Menurut Smiciklas (2012) dalam Anggraeni, R., \& Arfa, M. (2017) Infografis menyatukan teks dan gambar ke dalam suatu format tertentu yang diharapkan dapat dijadikan penyampaian informasi yang lebih mudah dan cepat dipahami oleh audience.

Ditambahkan oleh Aldila (2015) dalam Mansur H (2020) Media infografis sangatlah cocok digunakan pada sebuah pembelajaran yang membutuhkan minat baca yang tinggi. Minat baca yang tinggi bisa diperoleh dengan visualisasi data yang menarik. Salah satu media visualisasi data yang banyak dipakai adalah media infografis. Menurut Alrwele (2017) dalam Abidin 
(2019) Di era digital media pembelajaran sudah seharusnya dirancang mengikuti perkembangan teknologi. . Hal ini menyiratkan bahwa siswa "era digital" memerlukan pembelajaran "era digital" yang melibatkan representasi visual data untuk menarik perhatian mereka.

Berdasarkan dari latar belakang tersebut, maka penelitian ini membahas pembelajaran melalui pendekatan saintifik dengan memanfaatkan media infografis untuk meningkatkan kemampuan komunikasi (communication skill) dan hasil belajar siswa pada mata pelajaran Biologi di kelas XI MIPA 1 semester ganjil tahun pelajaran 2021/2022.

Berdasarkan rujukan dan fakta di atas, maka yang menjadi rumusan masalah dalam penelitian ini adalah "bagaimana proses pembelajaran saintifik, proses peningkatan kemampuan komunikasi ( communication skill ) siswa dan peningkatan hasil belajar siswa melalui pembelajaran saintifik dengan memanfaatkan media infografis pada mata pelajaran Biologi di kelas XI IPA 1 SMAN 1 Bengkulu Utara Tahun Pelajaran 2021/2022 ?”

Adapun tujuan penelitian ini untuk mendeskripsikan proses pembelajaran saintifik, mendeskripsikan peningkatan kemampuan komunikasi ( communication skill ) siswa dan mendeskripsikan peningkatan hasil belajar siswa melalui pembelajaran saintifik dengan memanfaatkan media infografis pada mata pelajaran Biologi di kelas XI IPA 1 SMAN 1 Bengkulu Utara Tahun Pelajaran 2021/2022.

\section{METODE PENELITIAN}

Penelitian penerapan pendekatan saintifik dengan memanfaatkan media infografis untuk meningkatkan kemampuan komunikasi. Jenis penelitian pada penelitian ini adalah Penelitian Tindakan Kelas (PTK). Kurniawan (2017) mengatakan bahwa Penelitian Tindakan Kelas (PTK) merupakan upaya dari seorang guru yang bertujuan untuk memperbaiki mutu proses belajar dikelasnya yang diawali dari refleksi diri sehingga dapat meningkatkan hasil belajar. Ditambahkan oleh Saputra (2021) Penelitian tidakan kelas merupakan sebuah penelitian yang diawali dari permasalahan yang terjadi di dalam kelas. Hasil kajian dari permasalahan tersebut dijadikan dasar untuk melakukan tindakan mengatasi permasalahan. Pelaksanaan tindakan diobservasi dan dievaluasi untuk bahan rujukan melakukan refleksi. Hasil pembahasan dari refleksi dijadikan dasar untuk menentukan perbaikan tindakan di siklus berikutnya. PTK ini dilakukan dalam tiga siklus yaitu Siklus I, II dan Siklus III. Desain penelitian setiap siklus mengacu pada model Kurt Lewin dimana dalam satu siklus terdiri atas empat langkah pokok, yaitu (1) perencanaan (planning), (2) tindakan (acting), (3) observasi (observing) dan (4) refleksi (reflecting).

Penelitian ini dilaksanakan pada bulan Juli sampai Oktober 2021 di SMAN 1 Bengkulu Utara. Adapun sabjek dalam penelitian ini adalah 31 orang siswa kelas XI MIPA 1 semester ganjil pada Tahun Pelajaran 2021/2022. Pembelajaran di lakukan menggunakan pendekatan saintifik dengan memanfaatkan media infografis untuk meningkatkan kemampuan komunikasi dan hasil belajar siswa. Penelitian ini dilakukan 3 siklus tiap satu siklus dengan dua pertemuan. Keterlaksanaan pembelajaran dengan pendekatan saintifik diamati dengan menggunakan lembar observasi, begitu juga dengan data kemampuan komunikasi siswa. Pengamatan keterlaksanaan pendekatan saintifik dan kemampuan komunikasi siswa diamati pada saat pembelajaran berlangsung. Lembar Observasi keterlaksanaan pendekatan saintifik berisi daftar ceklist langkah-langkah pendekatan saintifik. Indikator keterlaksanaan pendekatan saintifik adalah pada kategori baik (B). Lembar observasi kamampuan komunikasi siswa berisi daftar ceklist indikator kamampuan komunikasi (melihat lawan bicara, suara terdengar jelas, ekspresi wajah menyenangkan, menggunakan tata bahasa yang baik, dan pembicaraan dimengerti oleh penerima pesan). Siswa mampu menunjukan kemampuan komunikasi lisan yang baik dalam belajar sebanyak 10 orang dari 31 orang total sabjek penelitian. Data hasil belajar dengan menggunakan tes berupa soal esay uraian singkat diakhir siklus. Indikator hasil belajar siswa adalah sebanyak $75 \%$ siswa memperoleh nilai 75 (KKM kelas XI MIPA Tahun Pelajaran 
2021/2022). Pengolahan data keterlaksanaan proses pembelajaran saintifik dan kemampuan komunikasi siswa dengan menggunakan rumus:

$$
\text { Rata-rata }=\frac{\text { Jumlah skor pengamatan }}{\text { Jumlah total skor total pengamatan }} \times 100 \%
$$

(dimodifikasi Sugiyono dalam Sohaya, 2017)

Dengan kriteria interval keterlaksanaan proses pembelajaran saintifik dan kemampuan komunikasi antara lain; Interval $90 \leq \mathrm{A} \leq 100$ kategori baik sekali (BS), $80 \leq \mathrm{B} \leq 89$ kategori baik (B), $70 \leq \mathrm{C} \leq 78$ kategori cukup (C), $\leq 70$ kategori kurang (K).

\section{HASIL DAN PEMBAHASAN}

Hasil

Penelitian ini dilaksanakan di SMAN 1 Bengkulu Utara yang beralamat di Jalan Ir Soekarno No.1 Kecamatan Argamakmur, Kabupaten Bengkulu Utara. Kondisi awal Kelas XI MIPA1 pada tahun pelajaran 2021/2022 yang merupakan salah satu kelas tempat peneliti mengajar belum menunjukkan hasil belajar yang memuaskan serta kemampuan komunikasi yang baik. Data hasil belajar pada kondisi awal mata pelajaran Biologi di kelas XI MIPA 1 diambil dari hasil tes siswa pada materi kompetensi Dasar sebelumnya masih dalam kategori kurang, hanya 1 orang siswa yang mencapai tuntas.

Proses Pembelajaran saintifik dengan memanfaatkan media infografis berjalan lancar. Pada kegiatan inti diamati keterlaksanan proses pembelajaran saintifik dengan memanfaatkan media infografis. Pengamatan dilakukan pada pertemuan 1 dan pertemuan 2 oleh observer. Dari hasil pengamatan oleh 2 orang observer diperoleh data seperti pada Tabel 1 di bawah ini.

Hasil pencapaian dari data hasil observasi proses pembelajaran saintifik pada setiap siklus dapat dilihat pada Tabel 1 berikut.

Tabel 1. Data Hasil Obeservasi Proses Pembelajaran dengan Pedekatan Saintifik pada Setiap Siklus

\begin{tabular}{|c|c|c|c|c|c|c|c|}
\hline \multirow[b]{2}{*}{$\begin{array}{l}\text { Pengamatan Langkah } \\
\text { Pendekatan Saintifik }\end{array}$} & \multicolumn{2}{|c|}{ SIKLUS I } & \multicolumn{2}{|c|}{ SIKLUS II } & \multicolumn{2}{|c|}{ SIKLUS III } & \multirow[b]{2}{*}{ Keterangan } \\
\hline & $\%$ & Kriteria & $\%$ & Kriteria & $\%$ & Kriteria & \\
\hline Mengamati & 100 & $\mathrm{BS}$ & 100 & $\mathrm{BS}$ & 100 & $\mathrm{BS}$ & Meningkat \\
\hline Menanya & 100 & $\mathrm{BS}$ & 100 & $\mathrm{BS}$ & 100 & $\mathrm{BS}$ & Meningkat \\
\hline Mengumpulkan Informasi & 75 & $\mathrm{C}$ & 87,5 & $\mathrm{~B}$ & 100 & $\mathrm{BS}$ & Meningkat \\
\hline Menalar/Mengolah Informasi & 63 & $\mathrm{~K}$ & 75 & $\mathrm{C}$ & 88 & $\mathrm{~B}$ & Meningkat \\
\hline Mengkomunikasikan & 50 & $\mathrm{~K}$ & 75 & $\mathrm{C}$ & 88 & $\mathrm{~B}$ & Meningkat \\
\hline Rata-rata & 78 & & 88 & & 95 & & \\
\hline Kriteria & $\mathrm{C}$ & & $\mathrm{B}$ & & SB & & \\
\hline
\end{tabular}

Pada Tabel diatas terlihat bahwa data hasil observasi proses pembelajaran dengan pendekatan saintifik mengalami peningkatan pada Siklus I yaitu $78 \%$, Siklus II meningkat menjadi $88 \%$, dan pada siklus III meningkat menjadi 95\%. Indikator keberhasilan proses pembelajaran dengan pendekatan saintifik dalam penelitian ini adalah $80 \%$ kategori Baik (B). Sesuai dengan Tabel 2 di atas terlihat pada siklus II indikator keberhasilan sudah terpenuhi 
EDUTECH : Jurnal Inovasi Pendidikan Berbantuan Teknologi

Vol. 2 No. 1 Februari 2022, e-ISSN : 2797-0140 | p-ISSN : 2797-0590

Hasil pencapaian dari data hasil observasi kemampuan komunikasi siswa pada setiap siklus dapat dilihat pada Tabel 2 berikut.

Tabel 2. Data Hasil Observasi Kemampuan Komunikasi Siswa dengan Memanfaatkan Media Infografis pada Setiap Siklus

\begin{tabular}{cccccccc}
\hline & \multicolumn{2}{c}{ SIKLUS I } & \multicolumn{2}{c}{ SIKLUS II } & \multicolumn{2}{c}{ SIKLUS III } & \\
Pert & Jumlah & $\begin{array}{c}\text { Rata- } \\
\text { rata } \\
\text { Kriteria }\end{array}$ & Jumlah & $\begin{array}{c}\text { Rata- } \\
\text { rata } \\
\text { Kriteria }\end{array}$ & Jumlah & $\begin{array}{c}\text { Rata- } \\
\text { rata } \\
\text { Kriteria }\end{array}$ & Keterangan \\
\hline 1 & 2 & BS & 5 & K & 9 & BS & Meningkat \\
2 & 5 & B & 8 & BS & 14 & BS & Meningkat \\
\hline
\end{tabular}

Pada Tabel diatas terlihat bahwa data hasil observasi kemampuan komunikasi siswa dengan memanfaatkan media infografis mengalami peningkatan pada akhir Siklus I yaitu 5 siswa, Siklus II meningkat menjadi 8 siswa, dan pada siklus III meningkat menjadi 14 siswa. Indikator keberhasilan kemampuan komunikasi siswa dalam penelitian ini adalah 10 siswa memiliki kemampuan komunikasi Baik (B).

Data hasil pencapaian hasil belajar siswa pada setiap siklus dapat dilihat pada Tabel 3 berikut.

Tabel 3. Data Hasil Belajar Siswa dengan Memanfaatkan Media Infografis pada Setiap Siklus

\begin{tabular}{|c|c|c|c|c|c|c|}
\hline \multirow[b]{2}{*}{ Siswa Capai KKM } & \multicolumn{3}{|c|}{ SIKLUS II } & \multicolumn{2}{|c|}{ SIKLUS III } & \multirow[b]{2}{*}{ Keterangan } \\
\hline & $\begin{array}{c}\% \\
\text { Tuntas }\end{array}$ & $\begin{array}{l}\text { Siswa } \\
\text { Capai } \\
\text { KKM }\end{array}$ & $\begin{array}{c}\% \\
\text { Tuntas }\end{array}$ & $\begin{array}{l}\text { Siswa } \\
\text { Capai } \\
\text { KKM }\end{array}$ & $\begin{array}{c}\% \\
\text { Tuntas }\end{array}$ & \\
\hline 3,00 & 9,68 & 14,00 & 45,16 & 24 & 77,42 & Meningkat \\
\hline
\end{tabular}

Tabel diatas menunjukkan peningkatan yaitu pada Siklus I mencapai persentase siswa tuntas 9,16\%. Pada Siklus II mencapai 45,16\% dan pada Siklus III meningkat mencapai $77,42 \%$. Pencapaian hasil belajar tersebut sudah menunjukkan peningkatan dari siklus I, siklus II dan siklus III. Indikator keberhasilan hasil belajar adalah $75 \%$ siswa mencapai ketuntasan belajar (KKM) yaitu 75.

\section{Pembahasan}

Pembelajaran saintifik dengan memanfaatkan media infografis dilakukan pada Siklus I, Siklus II dan siklus III, masing-masing siklus terdiri dari tiga pertemuan. Pertemuan ke tiga merupakan evaluasi dengan menggunakan tes di akhir siklus. Pembelajaran Siklus I, II, dan III menggunakan urutan yang sama namun tidak sama persis karena pada Siklus II dan III sudah ada perbaikan dari hasil refleksi pada Siklus I dan Siklus II, sehingga hasil Siklus III lebih maksimal.

Keterlaksanaan proses pembelajaran saintifik meningkat yang terlihat pada siklus I keterlaksanaan pembelajaran saintifik $78 \%$ pada kategori kurang $(\mathrm{K})$, pada siklus II $88 \%$ kategori baik (B), dan pada siklus III menjadi 95\% pada kategori baik sekali (BS). Peningkatan ini terjadi karena pelaksanaan tahapan pembelajaran saitifik dilakukan sesuai dengan langkahlangkah pembelajaran saintifik. Kelemahan-kelemahan yang terjadi pada siklus I maupun pada siklus II langsung terekam dalam lembar observasi, dan kelemahan tersebut langsung diskusikan dengan observer dan siswa dan dicari solusinya. Kelemahan-kelemahan yang terlihat menjadi titik tolak untuk tindakan selanjutnya. Hasil refleksi diterapkan pada Tindakan berikutnya dan menjadi focus pengamatan peneliti.

Dalam penelitian ini menunjukkan proses pembelajaran saintifik, meliputi mengamati dengan menayangkan materi dengan memamfaatkan media infografis dan mencatat bagian- 
bagian penting, menanya dengan membantu siswa untuk merumuskan pertanyaan seputar materi, mengumpulkan informasi dengan membantu siswa untuk memilih sumber bacaan, menalar/mengolah informasi dengan memberikan kesempatan pada siswa untuk mengolah berbagai informasi seusai dengan materi yang ada pada infografis, dan mengkomunikasi dengan meminta siswa untuk menyampaikan hasil diskusi tentang materi secara lisan di depan kelas. Setiawan (2017) mengemukakan bahwa pendekatan saintifik tersusun atas beberapa langkah kegiatan yang berurutan, yaitu: mengamati, menanya, mengumpulkan informasi, melakukan percobaan, mengolah data, serta mengomunikasikan hasil. Langkah dalam pembelajaran saintifik tersebut dapat memberi pengalaman kepada siswa agar informasi pembelajaran yang diperoleh lebih bermakna, teruji, dan dapat dipertanggungjawabkan. Ditambahkan oleh Rusman (2015) bahwa pendekatan saintifik merupakan pendekatan pembelajaran yang memberikan kesempatan pada siswa untuk melakukan eksplorasi dan elaborasi materi yang dipelajari. Pembelajaran saintifik juga memberikan kesempatan pada peserta didik untuk mengaktualisasikan kemampuan melalui kegiatan pembelajaran yang dirancang oleh guru.

Kemampuan komunikasi dapat dilihat berdasarkan lembar observasi. Pada Tahapan pembelajaran saintifik diakhiri dengan tahapan mengkomunikasikan hasil diskusi. Siswa mengkomunikasikan hasil diskusi dengan memanfaatkan media infografis. Pada siklus I, siklus II, dan siklus III tahapan mengkomunikasikan hasil diskusi dilakukan secara lisan saja, terlihat siswa menjelaskan materi pada media infografis agar penyampaian hasil diskusi sesuai dengan tujuan pembelajaran.. Banyaknya siswa yang mampu berkomunikasi setiap siklusnya mengalami peningkatan. Di Akhir siklus III sebanyak 14 siswa mampu berkomunikasi dengan kategori baik sekali (BS).

Mengkomunikasikan hasil diskusi dengan memanfaatkan media infografis sangat membantu siswa dalam penyampaian hasil diskusi sehingga hasil diskusi tersampaikan secara sistematis. Menurut Khairani (2016), media pembelajaran adalah alat bantu pada proses belajar dalam rangka komunikasi interaksi guru dan siswa dalam proses pembelajaran. Dalam menciptakan salah satu media pembelajaran yang dapat diberikan kepada siswa adalah melalui media infografis. Ditambahkan oleh Miftah,dkk (2016) media infografis menjadi bentuk yang paling efektif untuk mengkomunikasikan informasi di era digital, maka dari itu media infografis sangatlah efektif untuk menyajikan informasi ke dalam bentuk visual. Senada dengan itu Sari, E.P. (2018) mengatakan media infografis mengandung ilustrasi yang menyajikan informasi secara runtut dan sistematis. Ilustrasi tersebut memperjelas materi dengan kombinasi gambar untuk memudahkan pembaca dalam mempelajari isi sebuah naskah.

Proses pembelajaran saintifik yang dilaksanakan sesuai dengan urutan langkah pembelajaran saintifik dengan memanfaatkan media infografis memberikan dampak pada hasil belajar siswa. Hasil belajar siswa pada siklus I, II dan III mengalami peningkatan. Pada siklus III siswa memperoleh ketuntasan belajar sebesar 77,42 \% yang sudah melebihi dari indikator keberhasilan yakni sebanyak $75 \%$.

Hasil penelitian ini juga didukung oleh penelitian Hidayat (2020) melakukan penelitian dengan judul penggunaan media ajar infografis melalui google classroom dalam upaya meningkatkan hasil belajar siswa pada materi sel. Penelitian ini bertujuan untuk mengetahui ada atau tidaknya pengaruh penggunaan media ajar infografis melalui google classroom terhadap hasil belajar siswa pada materi sel serta respon siswa terhadap pembelajaran tersebut. Hasil penelitian dapat disimpulkan bahwa kemampuan kognitif siswa dapat mengalami peningkatan sesudah diberikan perlakuan menggunakan media ajar infografis dalam pembelajaran di google classroom tersebut.

\section{KESIMPULAN}

Berdasarkan hasil penelitian tindakan kelas di atas dapat disimpulkan bahwa proses pembelajaran saintifik dengan memanfaatkan media infografis terlaksana semakin baik terbukti dapat meningkatkan kemampuan komunikasi dan hasil belajar siswa. Proses pembelajaran 
Vol. 2 No. 1 Februari 2022, e-ISSN : 2797-0140 | p-ISSN : 2797-0590

saintifik dengan memanfaatkan media infografis terlaksana dengan tingkat keterlaksanaan $78 \%$ pada Siklus I dengan kategori Cukup (C) menjadi 88\% dengan kategori Baik (B) pada Siklus II, dan menjadi 95\% dengan katagori Baik Sekali (BS) pada siklus III. Pembelajaran saintifik dengan memanfaatkan media infografis dapat meningkatkan kemampuan komunikasi siswa yaitu banyaknya siswa yang memiliki kemampuan komunikasi baik meningkat dari Siklus I sebesar 5 orang menjadi 8 orang di Siklus II, dan meningkat menjadi 14 orang pada siklus III. Seiring proses pembelajaran saintifik dengan memanfaatkan media infografis semangkin baik, hasil belajar juga meningkat yaitu banyaknya persentase siswa yang mencapai ketuntasan belajar dari Siklus I sebesar 9,68\% menjadi 45, 16\% di Siklus II, dan pada siklus III menjadi $77,42 \%$. Pembelajaran saintifik dengan memanfaatkan media infografis dapat digunakan oleh guru lainnya sesuai mata pelajaran dengan memperhatikan langkah -langkah pembelajaran saintifik dengan memanfaatkan media infografis ini.

\section{DAFTAR PUSTAKA}

Abidin, Z., \& Praherdhiono, H. (2019). Pengembangan Media Pembelajaran E-Book Infografis Sebagai Penguatan Kognitif Siswa X Mia. Jurnal Kajian Teknologi Pendidikan, 2(1), 37-44.

A. Lazard and L. Atkinson. (2015). "Putting Environmental Infographics Center Stage: The Role Of Visuals At The Elaboration Likelihood Model's Critical Point Of Persuasion," Science Communication, vol. 37, no. 1, pp. 6-33.

Anggraeni, R., \& Arfa, M. (2017). Efektivitas Produk Kemas Ulang Informasi Berupa Infografis Sebagai Media Pembelajaran Mata Pelajaran IPA (Studi Eksperimen Pada Siswa Kelas VII Di SMP N 1 Tembarak Kabupaten Temanggung). Jurnal Ilmu Perpustakaan, 6(1), 241-250.

Arigia, M. B., Damayanti, T., \& Sani, A. (2016). Sebagai Media Dalam Meningkatkan Pemahaman Dan Keterlibatan Publik Bank Indonesia. Jurnal Komunikasi, 8(2), 120133.

Arnyana, I. B. P. (2019). Pembelajaran Untuk Meningkatkan Kompetensi 4c (Communication, Collaboration, Critical Thinking Dancreative Thinking) Untukmenyongsong Era Abad 21. Prosiding: Konferensi Nasional Matematika dan IPA Universitas PGRI Banyuwangi, 1(1), i-xiii.

Daryanto. (2014). Pendekatan Pembelajaran Saintifik Kurikulum 2013. Yogyakarta: Penerbit Gava Media.

Sari, E. P. (2018). Pengembangan Media Berbentuk Infografis sebagai Penunjang Pembelajaran Fisika SMA Kelas X(Doctoral dissertation, UIN Raden Intan Lampung).

Hidayati, N. N., Aini, L. N., Novianty, A., Astutiningsih, T., \& Manurung, T. B. (2020). Metode Infografis Dalam Trigonometri Melalui Pembelajaran Daring Quizizz. Untuk Meningkatkan Pemahaman Siswa Kelas XI. MATH LOCUS: Jurnal Riset dan Inovasi Pendidikan Matematika, 1(2), 71-77.

Khairani, M. D. (2016). Pengembangan Media Pembelajaran Dalam Bentuk Macromedia Flash Materi Tabung Untuk SMP Kelas IX. Jurnal Ipteks Terapan, 10(2), 95-102.

Karar, E. E. dan Yenice, N. (2012). The Investigation Of Scientific Process Skill Level Of Elementary Education 8th Grade Students In View Of Demographic Features. Procedia Social and Behavioral Sciences.

Hidayat, S. T. (2020). Penggunaan Media Ajar Infografis Melalui Google Classroom Dalam Upaya Meningkatkan Hasil Belajar Siswa Pada Materi Sel (Doctoral dissertation, FKIP UNPAS).

Hosnan, M. (2014). Pendekatan Saintifik dan Kontekstual dalam Pembelajaran Abad 21. Bogor: Ghalia Indonesia.

Indriwati, S. E., Susilo, H., \& Anggrella, D. P. (2019). Penerapan Model Pembelajaran Inkuiri Terbimbing Berbasis Lesson Study Pada Matakuliah Keanekaragaman Hewan Untuk 
Meningkatkan Kecakapan Komunikasi Dan Hasil Belajar Kognitif Mahasiswa Pendidikan Biologi. Jurnal Pendidikan Biologi, 9(2), 38-46.

Miftah, M. N., Edwin, R., \& Rully, K. A. (2016). Pola Literasi Visual Infografer Dalam Pembuatan Informasi Grafis (Infografis). Jurnal Kajian Informasi \& Perpustakaan, 4(1), 87.

M. Smiciklas, (2012). The Power of Infographics: Using Pictures to Communicate and Connect with your Audiences, Indianapolis: QUE.

M. R. Umami, S. B. Utomo, and A. Ashadi, (2016). "Pengaruh Media Infografis Dan Poster Pada Pembelajaran Joyful Learning Terhadap Prestasi Belajar Siswa Ditinjau Dari Kemampuan Logika Pada Materi Pokok Kesetimbangan Kimia Kelas XI IPA Semester Gasal SMA Negeri Gondangrejo Tahun Pelajaran 2015/2016,” Jurnal Pendidikan Kimia,vol. 5, no. 3, pp. 9-17.

Mansur, H., \& Rafiudin, R. (2020). Pengembangan Media Pembelajaran Infografis untuk Meningkatkan Minat Belajar Mahasiswa. Jurnal Komunikasi Pendidikan, 4(1), 37-48.

Machin, A. (2014). Implementasi pendekatan saintifik, penanaman karakter dan konservasi pada pembelajaran materi pertumbuhan. Jurnal Pendidikan IPA Indonesia, 3(1).

Mansur, H., \& Rafiudin, R. (2020). Pengembangan Media Pembelajaran Infografis untuk Meningkatkan Minat Belajar Mahasiswa. Jurnal Komunikasi Pendidikan, 4(1), 37-48.

Nurhadi, Z. F., \& Kurniawan, A. W. (2018). Kajian Tentang Efektivitas Pesan dalam Komunikasi. Jurnal Komunikasi Universitas Garut: Hasil Pemikiran dan Penelitian, 3(1), 90-95.

Novita, L., Sukmanasa, E., \& Pratama, M. Y. (2019). Penggunaan Media Pembelajaran Video terhadap Hasil Belajar Siswa SD. Indonesian Journal of Primary Education, 3(2), 6472.

Pratiwi, A. A. Literature Review: Mengembangkan Skill Pembelajaran Dalam Menyongsong Pendidikan Abad 21.

Rahmawati, F., \& Shomad, Z. A. (2019). Analisis Hambatan Proses Pembelajaran Siswa Tunagrahita Di Kelas Inklusi. Konferensi Nasional Penelitian Matematika dan Pembelajarannya (KNPMP) IV Universitas Muhamadiyah Surakarta.

Saputra, Nanda ,dkk, (2021) Penelitian Tindakan Kelas. Penerbit: Yayasan Penerbit Muhammad Zaini. Aceh.

Sari, E. P. (2018). Pengembangan Media Berbentuk Infografis sebagai Penunjang Pembelajaran Fisika SMA Kelas X(Doctoral dissertation, UIN Raden Intan Lampung).

Setiawan, A. R. (2019). Penerapan Pendekatan Saintifik dalam Pembelajaran Biologi sebagai Upaya Melatih Literasi Saintifik. In Prosiding Seminar Nasional Biologi (pp. 140145).

Rianingsih, D., Mawardi, M., \& Wardani, K. W. (2019). Penerapan Model Pembelajaran TPS (Think Pair Share) Dalam Rangka Meningkatkan Keterampilan Komunikasi Siswa Kelas 3. NATURALISTIC: Jurnal Kajian Penelitian Pendidikan dan Pembelajaran, 3(2), 339-346.

Rusman. (2015). Pemebelajaran Tematik Terpadu. Jakarta: Raja Grafindo Persada.

Sjukur, S. B. (2012). Pengaruh Blended Learning Terhadap Motivasi Belajar Dan Hasil Belajar Siswa Di Tingkat SMK. Jurnal pendidikan vokasi, 2(3).

Zubaidah, S. (2016, December). Keterampilan Abad Ke-21: Keterampilan Yang Diajarkan Melalui Pembelajaran. In Seminar Nasional Pendidikan (Vol. 2, No. 2, pp. 1-17). 